\title{
Review and Prospect of Dynamic Managerial Capabilities Research
}

\author{
Qiaojuan Zou \\ Business School, Jiangxi Normal University, Nanchang, China
}

Keywords: dynamic managerial capability development; concept; component dimension

\begin{abstract}
Dynamic managerial capabilities are the ability of managers to use their knowledge and expertise to perceive opportunities and threats, seize opportunities, and reconfigure organizational resources. Dynamic managerial capabilities are of great importance to managers' decision-making and corporate development. So far, the conceptual definition and compositional dimensions of dynamic managerial capabilities are still unclear, which makes it difficult to study dynamic managerial capabilities. Based on the review of domestic and foreign literatures, this paper first reviews the existing research on the concept of dynamic managerial capabilities in foreign countries, and believes that the concept of dynamic managerial capabilities based on the theory of competency hierarchy is clear; then the dimensions of dynamic managerial capabilities are analyzed. In summary, it is believed that the managerial cognition, managerial social capital and managerial human capital, which are generally recognized by the current academic community, need to further deepen the research direction of the construction of the construction system. Finally, the results and shortcomings of the existing research are summarized, and the future research is prospected. .
\end{abstract}

\section{Introduction}

Dynamic managerial capabilities are a high-level capability for top management based on dynamic capabilities. More and more research shows that top management plays a crucial role in the external change of the company (Rosenbloom, 2000; TripsasandGavetti, 2000). In fact, Rosenbloom (2000) argues that individual leadership may be a "core element” of an organization's ability to change its genetic capabilities. In 2003, Adner and Helfat clearly proposed the term dynamic managerial capability, which was widely recognized by the academic community. Since then, research on dynamic managerial capabilities has been continuous. But there are still many disputes: First, there is no agreement on the definition of its concept; Second, at present, most of the research lacks the inheritance of existing research results and the integration of the latest research proposals, lacks the combing of the development of dynamic managerial capabilities, and there are serious differences in the division of dynamic managerial capabilities, resulting in the separation of relevant real research. conclusions are different or even contradictory. This paper aims to summarize the existing research on the concept of dynamic managerial capabilities, understand the development of dynamic managerial capabilities, collate the research on the division of existing dynamic managerial capabilities, and further clarify the dimensions of dynamic managerial capabilities, in order to lay a solid theoretical foundation for subsequent empirical research.

\section{The research review of dynamic managerial capabilities}

\subsection{Development history of dynamic managerial capabilities}

The study of dynamic managerial capabilities is inseparable from the inductive analysis of dynamic capabilities, which expands the perspective of dynamic capabilities (Eisenhardt \& Martin, 2000; Teece, Pisano \& Shuen, 1997), focusing on the individual and team roles of managers. Shang (Harris \& Helfat, 2013; Teece, 2012; Helfat \& Martin, 2014). Dynamic ability is to describe the high-level capabilities of enterprises. Teece and Pisano (1994) published "The Dynamic Capabilities of Firms: an Introduction", which clearly defines the concept of dynamic capabilities, which is defined as enterprise integration, the ability to build resources. Since then, scholars have conducted more continuous and developmental research based on Teece's classic conclusions. 
From 1990s to 2000s, at the beginning stage, there was no terminology of dynamic managerial capability. Research on management's ability mostly focused on the words "entrepreneurship", “entrepreneurial ability”, “innovation”, “competitive dynamics” and so on.

From 2000s to 2010s, during the development phase, Adner and Helfat (2003) explicitly proposed and defined the terminology of dynamic managerial capabilities. Since then, scholars have focused on the concept and divisional dimensions of dynamic managerial capabilities.

Since 2010s, the development stage has continued. In recent years, more and more scholars have begun to study the mechanism and construction research of manager's dynamic managerial capabilities, such as the relationship between dynamic managerial capabilities and corporate performance, dynamic managerial capabilities and decision-making, etc.

After studying the groundbreaking articles on dynamic capabilities of Teece et al., founding that there is a clear trend in the dynamic capability research process: more and more attention is paid to the micro level, that is, from the enterprise level to the individual level of employees. most of the current Research has focused on organizational factors that adapt companies to change. However, with the deepening and refinement of dynamic capabilities research, research has found that guidance from the top of the organization may have a major impact on how companies respond to changing environments.

The academic community has begun to focus on the dynamic capabilities of executives, namely dynamic managerial capabilities. Before the concept of dynamic managerial capability has been clearly stated, scholars use the words "dynamic ability" and "entrepreneurship" to describe the core competence of senior managers. For example, Rosenbloom (2000) argues that some CEOs may have the dynamic ability to help with strategic change. In 2003, Adner and Helfat helped to explain the senior management's decision-making on the external environment, which led to the heterogeneity of corporate performance. The article "CORPORATE EFFECTS AND DYNAMIC MANAGERIAL CAPABILITIES" was published in the Strategic Management Journal for the first time. The term dynamic managerial capability and its concepts are proposed. Since then, domestic and foreign scholars have used the term to conduct research (Sun Yuxiang, 2009; Liu Ligang et al., 2014; Fu Binghai et al., 2016; Buil-Fabregà, 2017). For example, Helfat et al. (2007) then use the term to refer to "the ability of an administrator to create, extend, or modify an organizational repository." Agarwal and Helfat (2009) further pointed out the importance of dynamic managerial capabilities in strategic updates. Later, Harris and Helfat (2013) extended the term to show that dynamic managerial capabilities can affect not only the internal attributes of an organization but also the external environment.

\subsection{Definition of dynamic managerial capabilities}

Many scholars believe that dynamic managerial ability is an advanced learning ability of individuals. The definition of its concept is inseparable from the three core competencies of integration, construction and reconfiguration capabilities. For example, Adner and Helfat(2003) argue that managers can leverage their knowledge and expertise to perceive opportunities and threats, seize opportunities, and reconfigure organizational resources, capabilities, and structures. Teece (2007) defines the "micro-foundation" of dynamic capabilities as (1) the ability to perceive opportunities and threats; (2) to seize opportunities by selecting possible actions, investing and deploying resources; and (3) reorganizing and transforming Organization and its resources and capabilities. O'Reilly and Tushman (2008) argue that dynamic managerial capabilities are "the ability of senior managers to ensure learning, integration, and reconfiguration and transformation when needed, all designed to perceive and seize opportunities." Zahra(2010) and others argue that dynamic capabilities reconfigure corporate resources and processes in ways that their key decision makers envision and consider appropriate, emphasizing the role of entrepreneurs in reconfiguring organizational resources and day-to-day activities. Sirmon et al. (2011) argue that a key dynamic managerial capability is the ability or skill that managers continually organize resources into bundles to extract more value from the pool of enterprise resources. Teece (2012) argue that for managers, dynamic managerial capabilities are the ability of entrepreneurial managers to create 
markets and orchestrate resources. Al-Aali and Teece (2014) study the relationship between entrepreneurship, business performance and dynamic capabilities, incorporating entrepreneurship and competence into dynamic capabilities, and believe that the dynamic competency framework is to some extent a whole organization that operates in an entrepreneurial manner. Ways. Helfat and Martin (2014) have three core foundations for dynamic managerial capabilities: managerial cognition, managed social capital, and managed human capital. Both Harris and Helfat (2015) executives and mid-level managers can have dynamic managerial capabilities, which are the ability of managers to create, extend or modify the way a for-profit company survives or perform its mission in a non-profit organization.

Domestic research on dynamic managerial capabilities is based on foreign research theories and started late. Sun Yuxiang (2009) is defined as the ability of enterprise managers to face the ever-changing environment and make rational use of enterprise resources. It consists of three elements: human capital, social capital and cognition of the executive team. Fu Huiming and Qin Yonghe (2014) put forward the dynamic ability of individual entrepreneurship, and believed that the dynamic ability of individual entrepreneurship includes intuitional shaping, integrated resilience, regional synergy, and absorption of learning. Liu Ligang and Tian Ruiyan (2014) mainly believe that the dynamic capabilities of enterprises exist in the decision-making of the top management team of the enterprise, and are influenced by the learning process of the senior management team of the enterprise. The process of information sharing, joint decision-making and collaborative behavior integration helps to pass Collective learning, the ability of the senior management team to learn personally to enhance the high-level dynamic capabilities of the enterprise.

\section{The theoretical interpretation of dynamic managerial capabilities: managerial cognition, managerial social capital and managerial human capital}

The relevant theoretical connotations of dynamic managerial capabilities have attracted the attention of scholars. On the dimension division of individual dynamic management ability, Helfat et al. (2014) put forward the divisional dimension of individual dynamic management ability based on Teece and Adner's research on individual dynamic ability, and get more recognition and use. dynamic managerial capabilities are divided into managerial cognition, managerial social capital, and managerial human capital. We briefly investigate each of the underlying theoretical literature as they relate to the dynamic managerial capabilities and the potential for strategic change, greatly extending and updating the discussion of Adner and Helfat.

Managerial cognition, includes mental models and beliefs (also known as knowledge structures; Eggers \& Kaplan, 2013), mental activities (management cognitive ability; Helfat \& Peteraf, 2014) and emotions (Hodgkinson \& Healey, 2011) . Considering that managers face a large variety of information, Walsh (1995) uses knowledge structures to replace their information cognition, which affects managers' judgments and decisions in the market. And specifically, Gray et al. (2012) and Helfat et al. (2014) argue that managers with prior experience in changing markets and organizations are more likely to develop knowledge structures that can be applied in a variety of environments. In addition, in addition to the knowledge structure, psychological processes and emotions are also the basis of managerial cognition. The psychological processes (also known as psychological activities) include attention and perception, reasoning and problem solving, communication and communication (Helfat, 2014). Regarding emotions, Zott and Huy (2014) believe that the ability to "emotional imitation" (manage and modify one's emotions) is an important element of dynamic managerial capabilities.

Managerial social capital refers to goodwill derived from formal and informal relationships, and managers share resources and information with others (Adler \& Kwon, 2002). Therefore, formal and informal working relationships (also known as interpersonal relationship management) provide managers with information channels that may help to perceive new opportunities (Adner \& Helfat, 2003). Managerial social capital to support the ability to seize opportunities and reconfigure dynamic managerial capabilities. For example, a central location in an internal social network can give power to resources that are useful for seizing opportunities. Similarly, internal power and 
influence from social capital may help to change the set involved in people, organizational structure, and reconfiguration. Therefore, when discussing social capital and dynamic capabilities, Blair and Cove (2003) argue that there is no individual social capital "the company will not be able to acquire, regroup and release resources”.

Managerial human capital, which manages "the core characteristics of human capital," such as knowledge, education, experience, and skills (Wright, Coff, and Moliterno, 2014). Becker (1964) conceptualized human capital refers to the skills and knowledge acquired by individuals through their prior experience, training and educational development. Recent research extends the concept to include not only knowledge and skills, but also the psychological attributes of individual cognitive abilities (general intelligence) and other abilities (personality, values, and interests) (Ployhart and Moliterno, 2011). Managers can use their knowledge and expertise to perceive opportunities and threats, seize opportunities, and reconfigure organizational resources, capabilities, and structures. Given the mastery of dynamic managerial capabilities, managers may influence the investments they make because of the differences in the expertise they have learned. Similarly, for reconfiguration, differences in management expertise gained from human capital may result in managers differing in the reconfiguration of organizational resources.

\section{Conclusions and prospects}

After nearly a decade of development, although the research on dynamic managerial capability still has problems such as unclear concept definition and lack of dimension division, the academic community has achieved some consensus on the basic concepts of dynamic managerial capabilities. In particular: First, agree that dynamic managerial ability is an ability that individuals possess, and most of these individuals are management. Second, dynamic managerial ability is a kind of advanced learning ability, with individual educational background and work experience. Third, dynamic managerial capabilities are developed from dynamic capabilities that describe individuals' ability to use their knowledge and expertise to perceive opportunities and threats, seize opportunities, and reconfigure organizational resources.

Although the existing research has achieved the above consensus on the basic concept of dynamic capabilities, this paper believes that the current research on dynamic managerial capabilities is still in the theoretical construction stage. In order to enrich the research of dynamic managerial capabilities and guide enterprise management practices, it is necessary to further deepen and improve the theoretical research of dynamic managerial capabilities. This paper finds that future research should also be broken or improved in the following aspects, in order to lay a solid foundation for follow-up research, and expand new development space for dynamic managerial capability research:

First, increase the localized empirical research on the constituent dimensions of dynamic managerial capabilities. At present, the authoritative dimension of dynamic managerial capability is Adner and Helfat (2003). Who divide the dynamic managerial capabilities into three dimensions of managerial cognition, managerial social capital and managerial human capital, and less domestic scholars conduct localization research. In the future, domestic scholars should combine the development background of China's institutional transformation. In addition to contributing to the basic theoretical issues of conceptual definition, dimension division and measurement of dynamic managerial capabilities, we should also carry out localized empirical research to improve the dynamic capability theory. Improve the universality of the theory and make more contributions.

Second, expending the study of the causes and consequences of dynamic managerial capabilities. Subsequent research should focus on the formation mechanism of dynamic managerial capabilities, the impact of dynamic managerial capabilities on firm performance and competitive advantage ,and its internal mechanisms, especially the relationship between dynamic managerial capabilities and competitive advantage. 


\section{References}

[1] Adner R, Helfat C E. Corporate effects and dynamic managerial capabilities[J]. Strategic Management Journal, 2003, 24(10):1011-1025.

[2] Fallonbyrne L, Harney B. Microfoundations of dynamic capabilities for innovation: a review and research agenda[J]. Irish Journal of Management, 2017, 36(1):21-31.

[3] Helfat C E, Martin J A. Dynamic managerial capabilities: Review and assessment of managerial impact on strategic change[J]. Journal of Management, 2015, 41(5):págs. 1291-1312.

[4] Mikalef P, Pateli A. Information technology-enabled dynamic capabilities and their indirect effect on competitive performance: Findings from PLS-SEM and fsQCA[J]. Journal of Business Research, 2017, 70:1-16.

[5] Ravishankar, M. N, Shan L. Examining the influence of modularity and knowledge management (KM) on dynamic capabilities: Insights from a call center[J]. International Journal of Information Management, 2013, 33(1):147-159.

[6] Rosenbloom RS. 2000. Leadership, capabilities, and technological change: the transformation of NCR in the electronic era. Strategic Management Journal,Special Issue 21(10-11): 1083-1104.

[7] Teece D J. Dynamic Capabilities: Routines versus Entrepreneurial Action[J]. Journal of Management Studies, 2012, 49(8):1395-1401.

[8] Wang C L, Ahmed P K. The development and validation of the organisational innovativeness construct using confirmatory factor analysis[J]. European Journal of Innovation Management, 2004, volume 7(4):303-313(11).

[9] Wang C L, Senaratne C, Rafiq M. Success Traps, Dynamic Capabilities and Firm Performance[J]. British Journal of Management, 2015, 26(1):26-44.

[10] Zahra S A, Sapienza H J, Davidsson P. Entrepreneurship and Dynamic Capabilities: A Review, Model and Research Agenda[J]. Journal of Management Studies, 2010, 43(4):917-955. 